\title{
Red List of Estonian Fungi - 2019 update
}

\author{
Irja Saar ${ }^{1}, J^{2}$ O Oja ${ }^{1}$, Kadri Póldmaa ${ }^{1}$, Kadri Pärtel ${ }^{1,2}$, Irma Zettur ${ }^{3}$, Urmas Kóljalg ${ }^{1,3}$ \\ ${ }^{1}$ Institute of Ecology and Earth Sciences, University of Tartu, Ravila St. 14A, 50411 Tartu, Estonia \\ E-mail: irja.saar@ut.ee \\ ${ }^{2}$ Mycological Collections, Institute of Agriculture and Environmental Sciences, Estonian University of Life Sciences, \\ Kreutzwaldi St. 5, 51006 Tartu, Estonia \\ ${ }^{3}$ Natural History Museum, University of Tartu, Ravila St. 14A, 50411 Tartu, Estonia
}

\begin{abstract}
In 2019 the conservation status of 214 fungal species in Estonia was assessed according to IUCN criteria and an IUCN category was assigned to each taxon. Altogether 94 species were categorized as threatened (CR, EN, VU), 42 least concern (LC), 60 near threatened (NT), three regionally extinct (RE) and six as data deficient (DD). Changes compared to the previous red list and threats to the species are discussed.
\end{abstract}

Kokkuvôte: Eesti seente Punane nimestik - 2019. aasta uuendus

2019. aastal hinnati 214 seeneliigi ohustatust Eestis kasutades IUCN kategooriaid ja kriteeriume. Hinnatud liikidest kuulus 94 ohustatuse kategooriatesse CR, EN ja VU, 42 hinnati kui soodsas seisundis (LC), 60 ohulähedased (NT), 3 piirkonnas välja surnud (RE) ja 6 puuduliku andmestikuga (DD). Artikkel käsitleb muudatusi vôrreldes eelmise punase nimestikuga ja olulisemate seeneliikide ohutegureid.

Keywords: Ascomycota, Basidiomycota, threats, red list

\section{INTRODUCTION}

The first Estonian Red Data Book, which was compiled in 1979 and published a few years later (Kumari, 1982), did not include any fungal species. However, the second Estonian Red List, compiled in 1988, comprised 12 non-lichenized fungal species (Kalamees, 1990; Anonymous, 1993) and the following Estonian Red Data Book (Lilleleht, 1998) included already 91 fungal species (Järva et al., 1998; Järva et al., 1999). Threatened taxa in the last list belonged to the phyla Ascomycota and Basidiomycota and were assigned to five categories based on intuitive criteria: 0 - extinct or probably extinct, 1 - endangered, 2 - vulnerable, 3 - rare, 4 - care demanding, 5 -indeterminate (no species belonged to the last category).

The revised version of Estonian Red Data Book, based on IUCN categories and established criteria (Standards and Petitions Working Group, 2006), was finished in 2008, with the data available at the Estonian biodiversity portal eElurikkus (Red Data Book of Estonia, 2008). The status of 183 fungal species in Estonia was assessed applying the seven categories adopted by IUCN. As a result, 119 species were evaluated as threatened (Critically Endangered - CR,
Endangered - EN, Vulnerable - VU) and five as Regionally Extinct.

The aim of this study is to present an updated Red List of Estonian fungi, except for lichenforming taxa and polypores, and to compare the current assessment with previous ones. For the first time, all Lactarius species and selected thelephoroid species were assessed due to the availability of specialists and sufficient data. In addition, the paper discusses the main habitats of threatened species and the major factors that endanger the distribution of these fungi in Estonia.

\section{MATERIAL AND METHODS}

The aim of the Environmental Board procurement, announced in 2019, was to carry out regional assessment of the threat status of selected fungal species occurring in Estonia, except for lichenised fungi and polypores that have been recently evaluated. Species from the two last groups, assessed to belong to the threatened categories CR, EN, VU have been outlined by Lõhmus et al. (2019) and Lõhmus et al. (2018). Due the limited time the following 
fungal taxa were selected for the assessment: 1) 135 species assessed in 2008 according to the Estonian Red Data Book (2008), including 33 species protected by law (Parmasto, 2006; I ja II kaitsekategooria...; III kaitsekategooria...); 2) all 75 species of Lactarius known from Estonia (as of 01.11.2018);

3) 20 selected species of Thelephorales.

Selection of resupinate thelephoroid species was based on specimen as well as rDNA ITS data available in UNITE and Estonian collection databases. Thelephoroid species may include cryptic species which are often formally not described. Therefore, we selected species where DNA sequence data are available for the precise identification and communication via UNITE DOI (digital object identifier) codes (Kõljalg et al., 2013). Fourteen of the assessed Lactarius species were excluded from the evaluation because of three main reasons:

1) synonymous species names;

2) species that have been misinterpreted in Estonia; or

3) species with unreliable reports in literature before 2000s that lack specimens in fungaria.

The species in the latter category usually belong to complex species groups, the taxonomy of which has been clarified only recently. Often, only the use of DNA sequence comparison can reliably distinguish such morphologically indistinguishable species. The data on the ecology and distribution of Estonian Lactarius species was summarized by Kuulo Kalamees (Kalamees, 2011), whose monograph includes valuable observation data from the last 60 years.

The threat status of the species was assessed based on the IUCN categories, criteria and guidelines (IUCN, 2012a, b), considering specifications of use for fungi (Dahlberg and Mueller, 2011). The possible conservation status of species was evaluated based on specimens in TAAM and TU fungaria and all data (rDNA ITS sequences, observations, reference-based occurrences) available in various public open databases (UNITE datasets, Kõljalg et al. 2013; Estonian Fungal Specimen National Database; Observations Database in PlutoF; Nature Observations Database in EELIS, Environmental registry) and in literature.

We have considered fungal species lacking any documented records after 1950 to be regionally extinct (RE). Due to lacking or limited data, only IUCN criteria A, B and D were used in the evaluation process.

\section{RESULTS AND DISCUSSION}

Out of the all 7692 fungal species registered in Estonia (according to open data in PlutoF, 10.05.2019), 220 polypore species were assessed in 2017 (Runnel, 2017; Lõhmus et al., 2018), and 214 non-lichenised species by the authors of the current paper in 2019 (see Supplement). Among these 434 assessed species, $36 \%$ have been categorized as least concern (LC), $35 \%$ species as threatened (CR, EN, VU), 18\% as near threatened (NT) and $2 \%$ as regionally extinct (RE). Species for which the category was data deficient (DD), not applicable (NA) or not evaluated $(\mathrm{NE})$ comprised $5 \%, 3 \%$ and $0.7 \%$ of the species, respectively (Table 1). The considerably high proportion of categories of threatened species is due to the fact that species in previous red lists formed the main part of taxa assessed in 2017 and 2019.

Table 1. The distribution of 434 fungal species for which conservation status in Estonia was evaluated in 2008 and later in 2017 (polypores) or 2019 among the IUCN categories

\begin{tabular}{lrrrc}
\hline Category & 2008 & 2017 & 2019 & $\begin{array}{l}2017+ \\
2019\end{array}$ \\
\hline Regionally extinct & 5 & 6 & 3 & 9 \\
Critically endangered & 45 & 11 & 25 & 36 \\
Endangered & 38 & 24 & 28 & 52 \\
Vulnerable & 36 & 24 & 41 & 65 \\
Near threatened & 44 & 20 & 60 & 80 \\
Least concern & 14 & 113 & 42 & 155 \\
Data deficient & 0 & 15 & 6 & 21 \\
Not applicable & 1 & 4 & 9 & 13 \\
Not evaluated & not ap- & 3 & not ap- & 3 \\
& plied & & plied & \\
\hline Total & 183 & 220 & 214 & 434 \\
\hline
\end{tabular}

Two species, Geoglossum atrovirens Kunze \& J.C. Schmidt and Leucopaxillus salmonifolius M.M. Moser \& Lamoure, assessed as CR in 2008 received NA in 2019 because there are no verified records of the former species and the only 
specimen from Estonia, identified as L. salmonifolius (TAAM182586) belongs to Notholepista subzonalis (= Leucopaxillus subzonalis) based on the comparison of ITS sequences (UDB017848/ SH1177032.08FU). The ITS sequence of the holotype of L. salmonifolius (UDB023944/ IB19750174) confirms the distinctness of this species (SH1551975.08FU).

Seventy-eight fungal species were assessed for the first time in 2019, of these 10 were assigned to the three threat categories (CR, EN, VU). Among the remaining 135 species that had been evaluated before, the threat category was raised for 10 , downgraded for 14 and left unchanged for 99 species. In case the species condition had deteriorated, it could directly be linked to the observed or suspected decline of the habitat area and quality, its predicted continuation and destruction of suitable habitats at the sites where the species had previously been observed. Upgrading was due to the observed increase in the size and/or number of known populations of the species. In Estonia, there are 153 (94 of these assessed in 2019) fungal species in the three threat categories (CR, EN, VU). Most of these species inhabit particular habitats, changes in which table 2 presents the main threat factors endangering their survival:

1) old-growth forests, the area of which has decreased rapidly in Estonia, also decline of wood of different tree species in various stages of decay (Lõhmus et al., 2004);

2) semi-natural habitats (meadows, alvars, parks, wooded meadows) where extensive management (grazing, mowing) has stopped;

3) decline of small-scale farming that limits suitable growth substrata, e.g. keratin-containing

Table 2. Threats to species assigned in threatened categories (CR, EN, VU) in 2019

\begin{tabular}{lc}
\hline Threat & Species (214) \\
\hline $\begin{array}{c}\text { Forestry (clear cutting, decrease of old- } \\
\text { growth forests, removal of wood) }\end{array}$ & 191 \\
$\begin{array}{c}\text { Altered management of semi-natural } \\
\text { communities }\end{array}$ & 11 \\
$\begin{array}{l}\text { Drainage of bogs (including ditching) } \\
\text { Sticking/ destroying the dunes }\end{array}$ & 1 \\
$\begin{array}{l}\text { Other (e.g. absence of suitable specific } \\
\text { substrate) }\end{array}$ & 5 \\
\hline
\end{tabular}

material (hoofs of horses or cows, cow horns) and horse manure (preferably from animals feeding on semi-natural pastures).

In addition, the fungal species at the margin (northern, north-eastern, eastern) of their species distribution range were treated as needing protection.

Most of the evaluated species in Estonia are endangered by forest management (clear cutting and other methods of intensive forestry), especially species that need long-lived stands for their growth. Habitats suitable for wooddecaying fungi have remarkably reduced because of removing fallen tree trunks and stumps during the intensive management of forests. Many species growing in association with broadleaved trees inhabit semi-open habitats, mostly woodland meadows, less frequently parks and alvar margins. All of these semi-natural habitats depend on regular extensive management: mowing, grazing and other activities that prevent their change to forests or thickets. The cessation of extensive management and resulting developing of these habitats into forests might also lead to the loss of their key species such as Quercus and Corylus. By contrast, intensive management, such as overgrazing and soil fertilization, can significantly reduce the frequency of the occurrence of several species.

The species evaluated in 2019 were dominated by ectomycorrhizal fungi $(60 \%)$, followed by saprotrophs on soil and litter (20\%) and wooddecayers $(17 \%)$; remaining four taxa are fungicolous (2), coprophilous (1) or decomposers of keratin-containing material (1) (Table 3).

The majority of the assessed ectomycorrhizal species in threatened categories (CR, EN, VU) grow either in Quercus-Corylus-Tilia dominated deciduous forests (including semi-open woodland-meadows) or conifer (Picea abies or Pinus sylvestris dominated) forests, with many species restricted to calcareous soil. Only a very few taxa are associated with other habitats, such as Amanita friabilis (P. Karst.) Bas (VU) in moist Alnus spp. forests. In Estonia, many of the red-listed ectomycorrhizal species are confined to the coastal calcareous regions, especially the Island of Saaremaa, where extensively managed, semi-open Quercus-Corylus woodlands as well as calcareous pine forests prevail. Because the 
Table 3. The assessed fungal species can be divided into following categories with respect to their lifestyle

\begin{tabular}{lcccc}
\hline Category & $\begin{array}{l}\text { Ectomycorrhizal } \\
\text { fungi }\end{array}$ & $\begin{array}{l}\text { Sapro- } \\
\text { trophs }\end{array}$ & $\begin{array}{l}\text { Wood- } \\
\text { decayers }\end{array}$ & Others \\
\hline $\mathrm{RE}$ & 2 & 0 & 1 & 0 \\
$\mathrm{CR}$ & 15 & 9 & 2 & 0 \\
$\mathrm{EN}$ & 13 & 6 & 8 & 1 \\
$\mathrm{VU}$ & 18 & 10 & 10 & 2 \\
$\mathrm{NT}$ & 32 & 14 & 13 & 1 \\
$\mathrm{LC}$ & 40 & 0 & 2 & 0 \\
$\mathrm{DD}$ & 3 & 2 & 1 & 0 \\
NA & 5 & 3 & 0 & 0 \\
\hline Total & 128 & 44 & 37 & 4 \\
\hline
\end{tabular}

distribution of many fungal groups in the Estonian calcareous forests, including alvars has not been assessed (e.g. Cortinarius and Entoloma as well as several saprotrophic species), further inventories of these habitats are needed.

Complete assessment of the genus Lactarius was performed for the first time. Altogether, the occurrence of 61 species in Estonia was confirmed, based on reliable (sequenced) fungarium material, more rarely sequences from ectomycorrhizal root tips. Many threatened Lactarius species are habitat-specialists, often associated solely with one or very few tree hosts, and are vulnerable to decline due to the decrease of suitable habitats. Some species, typically associated with the semi-open, calcareous deciduous woodlands, such as Lactarius mairei Malençon (CR) and $L$. acerrimus Britzelm. (VU), have their northernmost populations in Estonia. These seem to be associated with rare, declining habitats also in other regions, and are included in the red data lists of several North European countries.

Obviously, in order to understand the threat status of biota in complex ecosystems in Estonia, such as forests and semi-natural habitats, it is necessary to perform an IUCN assessment for a significantly larger number of fungal species. The evaluation of threat status revealed the need for taxonomic research and DNA barcoding in case of several species' complexes. In addition, many species have not been collected during the last decades, indicating a need for further monitories. Fungal inventories of semi-natural habitats (meadows, woodland meadows, alvars, parks) and marshes should particularly be initiated because fungal communities of these habitats have been rather poorly studied in Estonia.

\section{ACKNOWLEDGEMENTS}

The study was supported by the Environmental Board „Assessment of threat status of selected fungal species in Estonia (no 202812) project contract number 11-18/GY/875-5. We thank Dr. Ursula Peintner for sharing her unpublished ITS sequence from the holotype of Leucopaxillus salmonifolius, and reviewers Tor Erik Brandrud and Piret Lõhmus for improvements.

\section{REFERENCES}

I ja II kaitsekategooriana kaitse alla võetavate liikide loetelu. §6. II kaitsekategooria seeneliigid. 2004. Vabariigi Valitsuse 20. mai 2004. a. määrus nr 195, §6. Riigi Teataja I. 21.05.2004, 313.

III kaitsekategooria liikide kaitse alla võtmine. §2. III kaitsekategooria seeneliigid. 2004. Keskkonnaministri 19. mai 2004. a. määrus nr 51, §2. Riigi Teataja I, 27.05.2004, 1134.

Anonymous. 1993. "Eesti punane raamat", taimed, loomad ja seened (nov 1990). Eesti A \& O. Entsüklopeediakirjastus, Tallinn: 54-60.

Dahlberg, A., Mueller. G.M. 2011. Applying IUCN red-listing criteria for assessing and reporting on the conservation status of fungal species. Fungal Ecology 4: 147-162. https://doi.org/10.1016/j. funeco.2010.11.001

IUCN. 2012a. Guidelines for Application of IUCN Red List Criteria at Regional and National Levels: Version 4.0. Gland, Switzerland and Cambridge, UK: IUCN. iii+41 pp.

IUCN. 2012b. IUCN Red List Categories and Criteria: Version 3.1. Second edition. Gland, Switzerland and Cambridge, UK: IUCN. iv+32 pp.

Järva, L., Kalamees, K., Kullman, B., Parmasto, E., Raitviir, A., Saar, I., Vaasma, M. 1998. Red list of Estonian Fungi. In: Perini C. (Ed.). Conservation of fungi in Europe. Proceedings of the $4^{\text {th }}$ meeting of the European Council for the Conservation of Fungi, Vipiteno (Sterzing, Italy), 9-14 September 1997. Università degli Studi di Siena, Siena, Italy: pp. 136-138.

Järva, L., Kalamees, K., Kullman, B., Parmasto, E., Raitviir, A., Saar, I., Vaasma, M. (Toim. E. Parmasto). 1999. Distribution maps of Estonian fungi. Eesti seente levikuatlas 2. Protected species and species of the Estonian Red Data Book. Kaitsealused ja Eesti Punase raamatu liigid. Eesti Põllumajandusülikooli Zooloogia ja Botaanika Instituut, Tartu. 
Kalamees, K. 1990. Probleme des Pilzschutzes in der Estnischen SSR. Boletus 14 (2): 33-35.

Kalamees, K. 2011. Riisikad. Eesti elurikkus 1. Tartu Ülikooli Loodusmuuseum, Tartu.

Kumari, E. (ed.) 1982. Punane raamat. Eesti NSVs kaitstavaid taime- ja loomaliike. Tallinn.

Kõljalg, U., Nilsson, R.H., Abarenkov, K., Tedersoo, L., Taylor, A.F.S., Bahram, M., Bates, S.T., Bruns, T.D., Bengtsson-Palme, J., Callaghan, T.M., Douglas, B., Drenkhan, T., Eberhardt, U., Dueñas, M., Grebenc, T., Griffith, G.W., Hartmann, M., Kirk, P.M., Kohout, P., Larsson, E., Lindahl BD, Lücking R, Martín MP, Matheny PB, Nguyen, N.H., Niskanen, T., Oja, J., Peay, K.G., Peintner, U., Peterson, M., Põldmaa, K., Saag, L., Saar, I., Schüßler, A., Scott, J.A., Senés, C., Smith, M.E., Suija, A., Taylor, D.L., Telleria, M.T., Weiß, M., Larsson, K.-H. 2013. Towards a unified paradigm for sequence-based identification of Fungi. Molecular Ecology 22(21): 5271-5277. https://doi. org/ $10.1111 / \mathrm{mec} .12481$

Lilleleht, V. (ed.) 1998. Eesti Punane Raamat. Ohustatud seened, taimed ja loomad. Tartu.

Lõhmus, A., Kohv, K., Palo, A., Viilma, K. 2004. Loss of old-growth, and the minimum need for strictly protected forests in Estonia. In: Angelstam P., Donz-Breuss M., Roberge, J.-M. (Ed.). Targets and Tools for the Maintenance of Forest Biodiversity. Blackwell Science. Ecological Bulletins 51: 401-411.
Lõhmus, A., Vunk, E., Runnel, K. 2018. Conservation management for forest fungi in Estonia: the case of polypores. Folia Cryptogamica Estonica 55: 79-89. https:/ / doi.org/10.12697/fce.2018.55.08

Lõhmus, P., Marmor, L., Jüriado, I., Suija, A., Oja, E., Degtjarenko, P., Randlane, T. 2019. Red List of Estonian lichens: revision in 2019. Folia Cryptogamica Estonica 56: 63-76. https://doi. org/ $10.12697 /$ fce.2019.56.07

Parmasto, E. 2006. A new Estonian Nature Conservation Act. ECCF-Newsletter 14: 16-17.

Red Data Book of Estonia. 2008. Commission for Nature Conservation of the Estonian Academy of Sciences. http://vana.elurikkus.ut.ee/prmt. php?lang=eng (accessed 16 May 2019).

Runnel, K. 2017. Eesti torikseente looduskaitseline seisund. Environmental Investment Centre project no 10661 (in Estonian). Available at: https: / /www.zooloogia.ut.ee/sites/default/files / www_ut/kik10661_aruanne_0.pdf

Standards and Petitions Working Group 2006. Guidelines for Using the IUCN Red List Categories and Criteria: Version 6.1. Prepared by the Standards and Petitions Working Group for the IUCN SSC Biodiversity Assessments Sub-Committee in July 2006. Downloadable from http://app.iucn.org/ webfiles/doc/SSC/RedList/RedListGuidelines. pdf. 
Supplement. Estonian Red List of selected fungal species compiled in 2019. For abbreviations of categories see Results and Discussion. IUCN category and criteria of 2008 are not presented if identical to 2019.

\begin{tabular}{|c|c|c|c|}
\hline Species & IUCN category/ criteria 2019 & $\begin{array}{l}\text { IUCN category/ } \\
\text { criteria } 2008\end{array}$ & $\begin{array}{l}\text { Protected by the law } \\
\text { (categories I-III) }\end{array}$ \\
\hline Catathelasma imperiale & $\mathrm{RE}$ & & \\
\hline Sarcodontia crocea & RE & & \\
\hline Tricholoma acerbum & RE & & \\
\hline Butyriboletus fechtneri & CR B2ab(iii); D & & II \\
\hline Caloboletus calopus & CR B2ab(iii); D & & \\
\hline Cantharellus melanoxeros & CR B2ab(iii); D & & II \\
\hline Chamaemyces fracidus & CR B2ab(iii); D & & II \\
\hline Geastrum berkeleyi & CR B2ab(iv); D & & \\
\hline Geastrum elegans & CR B2ab(iii); D & & \\
\hline Hemileccinum impolitum & CR B2ab(iii); D & & II \\
\hline Hygrocybe intermedia & CR B2ab(iii); D & & \\
\hline Hygrocybe russocoriacea & CR B2ab(iii); D & & \\
\hline Hygrocybe spadicea & CR B2ab(iii); D & $\mathrm{RE}$ & \\
\hline Hygrophorus hyacinthinus & CR B2ab(iii); D & & \\
\hline Lactarius auriolla & CR B2ab(iii); D & & \\
\hline Lactarius hysginus & CR B2ab(iii); D & & \\
\hline Lactarius mairei & CR B2ab(iii); D & & II \\
\hline Lactarius serifluus & CR B2ab(iii); D & & \\
\hline Lilaceophlebia tremelloidea & CR B2ab(iii); D & & \\
\hline Microglossum atropurpureum & CR B2ab(iii); D & & II \\
\hline Peziza ammophila & CR B2ab(iii, iv), D & & II \\
\hline Poronia punctata & CR A2c; B2ab(iii, iv); D & VU D1 & \\
\hline Porphyrellus porphyrosporus & CR B2ab(iii); D & EN D1 & \\
\hline Punctularia strigosozonata & CR B2ab(iii); D & & \\
\hline Ramaria botrytis & CR B2ab(iv); D & & \\
\hline Sarcodon fuligineoviolaceus & CR B2ab(iii); D & & I \\
\hline Sutorius luridiformis & CR B2ab(iii); D & EN B1; D1 & II \\
\hline Tricholoma colossus & CR B2ab(iii); D & & III \\
\hline Morchella semilibera & EN B2ab(iii,iv); D & CR B1; D1 & II \\
\hline Amanita strobiliformis & EN B2ab(iii); D & & \\
\hline Asterodon ferruginosus & EN B2ab(iii); D & CR A2a & \\
\hline Asterostroma cervicolor & EN B2ab(iii); D & CR D1 & \\
\hline Aureoboletus gentilis & EN B2ab(iii); D & & \\
\hline Bankera violascens & EN B2ab(iii); D & & III \\
\hline Bovista paludosa & EN B2ab(iii, iv); D & & II \\
\hline Geastrum coronatum & EN B2ab(iv); D & VU D2 & \\
\hline Geastrum striatum & EN B2ab(iv) & VU D1 & \\
\hline Hemistropharia albocrenulata & EN B2ab(iii); D & & \\
\hline Hydnellum auratile & EN B2ab(iii); D & & \\
\hline Hygrocybe punicea & EN B2ab(iii, v); D & VU D1 & \\
\hline Hygrophorus chrysodon & EN B1ab(iii); D & & II \\
\hline
\end{tabular}




\begin{tabular}{|c|c|c|c|}
\hline Species & IUCN category/ criteria 2019 & $\begin{array}{l}\text { IUCN category/ } \\
\text { criteria } 2008\end{array}$ & $\begin{array}{l}\text { Protected by the law } \\
\text { (categories I-III) }\end{array}$ \\
\hline Hygrophorus russula & EN B2ab(iii); D & & \\
\hline Kavinia alboviridis & EN B2ab(iii); D & & \\
\hline Lactarius chrysorrheus & EN B2ab(iii); D & CR D1 & II \\
\hline Lactarius controversus & EN B2ab(iii); D & & II \\
\hline Microstoma protractum & EN A2c; B2ab(ii); D & VU D1 & \\
\hline Mutinus caninus & EN B2ab(iv); D & VU D1 & \\
\hline Onygena equina & EN A2c; D & & \\
\hline Pseudotomentella nigra & EN B2ab(iii); D & & \\
\hline Pseudotomentella vepallidospora & EN B2ab(iii); D & & \\
\hline Rhodotus palmatus & EN B2ab(iii); D & & I \\
\hline Steccherinum robustius & EN B2ab(iii); D & & \\
\hline Stereopsis vitellina & EN B2ab(iii); D & & \\
\hline Tomentella atroarenicolor & EN B2ab(iii); D & & \\
\hline Tricholoma apium & EN B1ab(iii); D & & II \\
\hline Tricholomella constricta & EN B1ab(iii, v); D & & \\
\hline Amanita friabilis & VU D1 & & II \\
\hline Amaurodon mustialaensis & VU D1 & $\mathrm{EN} \mathrm{A3c}$ & \\
\hline Bolbitius variicolor & VU B2ab(ii, iii); D1 & & \\
\hline Caloboletus radicans & VU D1 & EN B1; D1 & II \\
\hline Chlorencoelia versiformis & VU D1 & & \\
\hline Clavulinopsis corniculata & VU B2ab(iv); D1 & & III \\
\hline Dentipellis fragilis & VU D1 & EN A2a & \\
\hline Entoloma bloxamii & VU B2ab(iii, v); D1 & NT & II \\
\hline Eocronartium muscicola & VU D1 & & \\
\hline Gloiodon strigosus & VU D1 & EN A2a; D1 & \\
\hline Gomphus clavatus & VU A2c; D1 & & \\
\hline Gyroporus castaneus & VU B2ab(iii); D1 & & \\
\hline Hohenbuehelia petaloides & VU D1 & CR B1; D1 & \\
\hline Hydnellum aurantiacum & VU D1 & & \\
\hline Hygrophorus piceae & VU B2ab(iii); D1 & & \\
\hline Hypholoma flavorhizum & VU B2ab(iii); D1 & & \\
\hline Hypocreopsis lichenoides & VU D1 & & \\
\hline Ionomidotis irregularis & VU D1 & & \\
\hline Lactarius acerrimus & VU D1 & not assessed & \\
\hline Lepiota grangei & VU D1 & CR B1; D1 & \\
\hline Marasmius wynneae & VU D1 & EN B1; D1 & \\
\hline Odontia ferruginea & VU D1 & not assessed & \\
\hline Phellodon fuligineoalbus & VU D1 & & III \\
\hline Phellodon niger & VU D1 & & III \\
\hline Phleogena faginea & VU D1 & & \\
\hline Rugosomyces ionides & VU D1 & & \\
\hline Sabuloglossum arenarium & VU D1 & & II \\
\hline Sarcosoma globosum & VU A2c; D1 & & I \\
\hline Sarcosphaera coronaria & VU D1 & & II \\
\hline
\end{tabular}




\begin{tabular}{|c|c|c|c|}
\hline Species & IUCN category/ criteria 2019 & $\begin{array}{l}\text { IUCN category/ } \\
\text { criteria } 2008\end{array}$ & $\begin{array}{l}\text { Protected by the law } \\
\text { (categories I-III) }\end{array}$ \\
\hline Sowerbyella imperialis & VU D1 & NT & III \\
\hline Sowerbyella radiculata & VU D1 & NT & \\
\hline Sparassis crispa & VU D1 & EN D1 & II \\
\hline Thelephora caryophyllea & VU D1 & & \\
\hline Tomentella botryoides & VU D1 & not assessed & \\
\hline Tomentella galzinii & VU D1 & not assessed & \\
\hline Tomentella subclavigera & VU D1 & not assessed & \\
\hline Tomentella subtestacea & VU D1 & not assessed & \\
\hline Tomentella viridula & VU D1 & not assessed & \\
\hline Tulostoma fimbriatum & VU D1 & & \\
\hline Xylaria polymorpha & VU D1 & & \\
\hline Xylobolus frustulatus & VU D1 & & \\
\hline Auricularia mesenterica & NT & & \\
\hline Bulgaria inquinans & NT & & \\
\hline Caloscypha fulgens & NT & & \\
\hline Geastrum minimum & NT & & \\
\hline Geastrum rufescens & NT & & \\
\hline Geastrum schmidelii & NT & & \\
\hline Geastrum triplex & NT & & \\
\hline Guepinia helvelloides & NT & & \\
\hline Gyroporus cyanescens & NT & & \\
\hline Hericium coralloides & NT & & \\
\hline Holwaya mucida & NT & & \\
\hline Hydnellum ferrugineum & NT & & \\
\hline Hymenochaete ulmicola & NT & & \\
\hline Hypholoma radicosum & NT & & \\
\hline Kuehneromyces lignicola & NT & & \\
\hline Laccaria maritima & NT & & \\
\hline Lactarius citriolens & NT & not assessed & \\
\hline Lactarius fennoscandicus & NT & not assessed & \\
\hline Lactarius flavopalustris & NT & not assessed & \\
\hline Lactarius fuliginosus & NT & not assessed & \\
\hline Lactarius fulvissimus & NT & not assessed & \\
\hline Lactarius leonis & NT & not assessed & \\
\hline Lactarius lignyotus & NT & not assessed & \\
\hline Lactarius luridus & NT & not assessed & \\
\hline Lactarius musteus & NT & not assessed & \\
\hline Lactarius pilatii & NT & not assessed & \\
\hline Lactarius piperatus & NT & not assessed & \\
\hline Lactarius repraesentaneus & NT & not assessed & \\
\hline Lactarius resimus & NT & not assessed & \\
\hline Lactarius sanguifluus & NT & not assessed & \\
\hline Lactarius semisanguifluus & NT & not assessed & \\
\hline Lactarius sphagneti & NT & not assessed & \\
\hline
\end{tabular}




\begin{tabular}{|c|c|c|c|}
\hline Species & IUCN category/ criteria 2019 & $\begin{array}{l}\text { IUCN category/ } \\
\text { criteria } 2008\end{array}$ & $\begin{array}{l}\text { Protected by the law } \\
\text { (categories I-III) }\end{array}$ \\
\hline Lactarius vellereus & NT & not assessed & \\
\hline Lactarius volemus & NT & not assessed & \\
\hline Lactarius zonarioides & NT & not assessed & \\
\hline Lactarius zonarius & NT & not assessed & \\
\hline Lentaria epichnoa & NT & & \\
\hline Leucoagaricus nympharum & NT & & II \\
\hline Leucopaxillus compactus & NT & & II \\
\hline Lycoperdon caudatum & NT & & \\
\hline Lycoperdon echinatum & NT & & \\
\hline Marchandiomyces quercinus & NT & & \\
\hline Mycenastrum corium & NT & & \\
\hline Neottiella hetieri & NT & & \\
\hline Pleurotus calyptratus & NT & & \\
\hline Pseudotomentella mucidula & NT & not assessed & \\
\hline Rubroboletus satanas & NT & & \\
\hline Sarcodon glaucopus & NT & & \\
\hline Sistotrema raduloides & NT & & \\
\hline Suillus collinitus & NT & EN B1; D1 & \\
\hline Thelephora penicillata & NT & & \\
\hline Tolypocladium capitatum & NT & & \\
\hline Tomentella asperula & NT & not assessed & \\
\hline Tomentella badia & NT & not assessed & \\
\hline Tomentella cinerascens & NT & not assessed & \\
\hline Tomentellopsis zygodesmoides & NT & not assessed & \\
\hline Tulostoma brumale & NT & & \\
\hline Verpa digitaliformis & NT & & \\
\hline Volvariella bombycina & NT & & \\
\hline Xerula pudens & NT & & \\
\hline Athelia arachnoidea & LC & & \\
\hline Lactarius aquizonatus & $\mathrm{LC}$ & not assessed & \\
\hline Lactarius aspideus & $\mathrm{LC}$ & not assessed & \\
\hline Lactarius aurantiacus & $\mathrm{LC}$ & not assessed & \\
\hline Lactarius azonites & $\mathrm{LC}$ & not assessed & \\
\hline Lactarius badiosanguineus & $\mathrm{LC}$ & not assessed & \\
\hline Lactarius camphoratus & $\mathrm{LC}$ & not assessed & \\
\hline Lactarius cyathuliformis & $\mathrm{LC}$ & not assessed & \\
\hline Lactarius deliciosus & $\mathrm{LC}$ & not assessed & \\
\hline Lactarius deterrimus & $\mathrm{LC}$ & not assessed & \\
\hline Lactarius evosmus & $\mathrm{LC}$ & not assessed & \\
\hline Lactarius flexuosus & $\mathrm{LC}$ & not assessed & \\
\hline Lactarius glyciosmus & $\mathrm{LC}$ & not assessed & \\
\hline Lactarius helvus & $\mathrm{LC}$ & not assessed & \\
\hline Lactarius lacunarum & $\mathrm{LC}$ & not assessed & \\
\hline Lactarius lilacinus & $\mathrm{LC}$ & not assessed & \\
\hline
\end{tabular}




\begin{tabular}{|c|c|c|c|}
\hline Species & IUCN category/ criteria 2019 & $\begin{array}{l}\text { IUCN category/ } \\
\text { criteria } 2008\end{array}$ & $\begin{array}{l}\text { Protected by the law } \\
\text { (categories I-III) }\end{array}$ \\
\hline Lactarius mammosus & $\mathrm{LC}$ & not assessed & \\
\hline Lactarius necator & $\mathrm{LC}$ & not assessed & \\
\hline Lactarius obscuratus & $\mathrm{LC}$ & not assessed & \\
\hline Lactarius olivinus & $\mathrm{LC}$ & not assessed & \\
\hline Lactarius pubescens & $\mathrm{LC}$ & not assessed & \\
\hline Lactarius pyrogalus & $\mathrm{LC}$ & not assessed & \\
\hline Lactarius quieticolor & LC & not assessed & \\
\hline Lactarius quietus & $\mathrm{LC}$ & not assessed & \\
\hline Lactarius rufus & $\mathrm{LC}$ & not assessed & \\
\hline Lactarius scoticus & $\mathrm{LC}$ & not assessed & \\
\hline Lactarius scrobiculatus & $\mathrm{LC}$ & not assessed & \\
\hline Lactarius spinosulus & $\mathrm{LC}$ & not assessed & \\
\hline Lactarius tabidus & $\mathrm{LC}$ & not assessed & \\
\hline Lactarius torminosus & $\mathrm{LC}$ & not assessed & \\
\hline Lactarius trivialis & $\mathrm{LC}$ & not assessed & \\
\hline Lactarius uvidus & LC & not assessed & \\
\hline Lactarius vietus & $\mathrm{LC}$ & not assessed & \\
\hline Lactarius violascens & LC & not assessed & \\
\hline Phyllotopsis nidulans & $\mathrm{LC}$ & NT & \\
\hline Pseudotomentella tristis & LC & not assessed & \\
\hline Tomentella bryophila & $\mathrm{LC}$ & not assessed & \\
\hline Tomentella ferruginea & $\mathrm{LC}$ & not assessed & \\
\hline Tomentella punicea & LC & not assessed & \\
\hline Tomentella stuposa & $\mathrm{LC}$ & not assessed & \\
\hline Tomentellopsis echinospora & $\mathrm{LC}$ & not assessed & \\
\hline Tomentellopsis submollis & $\mathrm{LC}$ & not assessed & \\
\hline Butyriboletus appendiculatus & DD & CR B1; D1 & \\
\hline Clavulina amethystina & DD & CR D1 & \\
\hline Clitocella mundula & DD & CR B1; D1 & \\
\hline Pterula multifida & DD & EN D1 & \\
\hline Sowerbyella rhenana & DD & NT & \\
\hline Strobilomyces strobilaceus & DD & CR B1; D1 & \\
\hline Gomphidius maculatus & NA & NT & \\
\hline Lactarius circellatus & NA & $\mathrm{LC}$ & \\
\hline Lactarius rostratus & NA & not assessed & \\
\hline Lactarius ruginosus & NA & not assessed & \\
\hline Leucopaxillus salmonifolius & NA & CR B1; D1 & I \\
\hline Microglossum atrovirens & NA & CR B1; D1 & \\
\hline Mutinus ravenelii & NA & NT & \\
\hline Suillus americanus & NA & NA & \\
\hline Suillus cavipes & NA & EN D1 & II \\
\hline
\end{tabular}

